\title{
КЛАСТЕРЖУУЛЭХ ПРОЦЕСС: ЧАЦАРГАНЫ КЛАСТЕРИЙН САНААЧИЛГЫН ЖИШЭЭ
}

\author{
Х.Цэвэлмаа
}

Монгол Улсын Их Сургууль, Монгол улс Цахим шуудан: tsvlmkhrgs@gmail.com

\section{ХУРААНГУЙ}

Уламжлалт салбаруудыг кластержүҮлэхэд судалгаа, шинжилгээний ажлын эрэлт их байна. Кластер бол эдийн засгийн хөгжлийн шинэ хандлага юм. Иймд нэг талаас улс орны эдийн засгийн хөгжлийн хандлагыг ул суурьтай судлах; нөгөө талаас эдийн засгийн хөгжлийн динамик бүтиийг шинжлэх хийгээд түүнд шаардлагатай тоо мэдээллийг иуглуулахад хугаиаа их шаардагдаж байна. Энэ ажлаар эдийн засгийн хөгжлийн харьцангуй шинэ, динамик загвар болох кластерийг Монголын хөрсөнд буулгахаар туршиж байгаа үйл явиыг харуулж, улмаар кластерийн бодлого боловсруулах нь зайлигүй болэ байгааг үзүүлэх зорилгоор энэхүУ судалгааг гүйиэтгэв. Энэ ажльнн эхний хэсэгт кластер, кластерийн санаачилгын судалгааны үр дүн, үр нөлөөг тоймлон үзүүллээ. Дараагийн хэсэгт кластержсүлэх арга зүйг товч авч үзнэ. Төгсгөлд нь, кластержүүлэх процессийг Монгол улсад хэрэгжиж буй чащарганы кластерийн санаачилгын үйл ажиллагаагаар харуулна. Үүний үр дүнд уламжлалт салбаруудыг хөндлөн өртгийн сүлжээ руҮ татах замаар кластерийг хөгжүүлбэл урт хугаиаандаа худалдааны хамтын ажиллагааг бэхжүүлж болно. Энэ нөхиөлд кластерийн санаачилга нь богино ба дунд хугаиаанд 2-3 хамгийн чухал зорилтыг хамтын ажиллагааны институиийг бэхжүүлэхээр сонговол эдийн засгийн бүсийг ялгаатай төрөлэсүүлэ үндэс болох төдийгүй Монгол улсад кластерийн бодлого боловсруулах нь зайлигүй гэдгийг ҮзүҮлнэ.

Түлхүур үгс: кластерийн санаачилга, хөндлөн өртгийн сүлэсээний дагуух холбоотой салбарууд, кластерийн бодлого;

\section{ОРШИЛ}

Харвардын Стратеги, өрсөлдөөний хүрээлэнгээс санаачилсан “Өрсөлдөх чадварын микро эдийн засаг”-ийн сүүлийн 15 жилийн хугацаанд хэрэгжүүлсэн судалгаа, эрдэм шинжилгээний ажлын хүрээнд 527 үндэсний болон бүс нутгийн өрсөлдөх чадварын санаачилга, 470 кластерийн санаачилгын төсөл хэрэгжиж, 332 кейс, 668 өрсөлдөх чадварын судалгааны төсөл, судлаачдын 63 хамтарсан төсөл хэрэгжжээ. [1] Эдгээр 470 кластерийн санаачилгын төсөл дотор 2015 оноос ХХААЯ-аас хэрэгжүүлж эхэлсэн Чацарганы кластерийн санаачилга (ЧКС) 
багтаж байгаа юм.

2003 онд хийгдсэн Кластерийн санаачилгын түүвэр судалгааны үр дүнгээс харвал, “кластерийн санаачилгын 32 хувийг засгийн газар...” эхлүүлсэн [2] гэсэн судалгааны үр дүн гарч байсан бөгөөд энэхүҮ Чацарганы кластерийн санаачилгыг ХХААЯ эхлүүлсэн байна. 2012 оноос хойш хийгдсэн удаа дараагийн судалгааны үр дүн, зөвлөмжинд суурилан ЧКС нь стратегийн зорилго, зорилтыг тодорхойлж, 20162018 онд хэрэгжүүлэх үйл ажиллагааны төлөвлөгөөгөө гаргасан.

ЧКС төслийг хувийн хэвшлийн компани болон эрдэм шинжилгээний байгууллагын консорциум эхлүүлж, төслийн удирдлага, зохион байгуулалт, хэрэгжүүлэлтийг Монголын жимс жимсгэний үндэсний холбооны дэргэдэх судалгааны баг хариуцан ажиллаж байгаа бөгөөд хамтын ажиллагааны институцийн Монголд нийцэх шинэ хэлбэрийг төлөвшүүлэн салбаруудыг бизнесийн мөчлөгийн дагуу хөгжүүлэх зорилготой.

Салбаруудыг кластераар хөгжүүлэх нь өөрөө урт хугацааны тасралтгүй үйл ажиллагаа учраас гол төлөв хөндлөн өртгийн сүлжээний дагуух холбоотой салбаруудын эдийн засгийн үйл ажиллагааны тасалдал, гажуудал, уялдаа холбоогүй байдлыг л засаад явбал зах зээлийн болон засгийн газрын сул талыг засах боломж олгохоор байна. [3]

Монгол улсад салбаруудыг кластераар хөгжүүлэх туршилт судалгаa 2012 онд хийгдсэн. Энэхүу сонгосон салбарын нөхцөл байдлын үнэлгээгээр жимс жимсгэний өртгийн сүлжээний дэмжих үйл ажиллагаанд тулгарч буй асуудлын эрэмбэ дараалал, зохицуулалтын сул талыг илрүүлсэн. Мөн жимс жимсгэний өртгийн сүлжээний анхан шатны үйл ажиллагаанд өртгийн сүлжээний шат дамжлагад өртөг нэмэгдэж чадахгүй байгаa шалтгааныг илрүүлсээр байна. Жимс жимсгэний өртгийн сүлжээний дэмжих үйл ажиллагаанд Засгийн газрын худалдан авалт, санхүүгийн институцийн өртгийн сүлжээний санхүүжилтийн бүтээгдэхүүн, үйлчилгээний дэмжлэг их дутагдалтай. Харин жимс жимсгэний өртгийн сүлжээний анхан шатны үйл ажиллагаанд жимсний нөөц бэлтгэл болон шинэ бүтээгдэхүүний судалгаа, хөгжилд анхаарал хандуулах шаардлагатай. Монгол улсын жимс жимсгэний өртгийн сүлжээний дэмжих болон анхан шатны үйл ажиллагааг уялдуулахад холбогчийн үүрэг, мөн анхан шатны үйл ажиллагаанд манлайлагчийн үүрэг зайлшгүй. 2016 оноос хойш жимс жимсгэний өртгийн сүлжээн дэх дэмжих болон анхан шатны үйл ажиллагааг уялдуулахад холбогчийн үүргийг Монголын жимс жимсгэний үндэсний холбоо гүйцэтгэж байгаа нь оролцогч талуудын хувийн сонирхлыг нэгэн зэрэг хангах талтай. Холбоотой болон бие биенийгээ дэмжих салбарууд доторхи манлайлагчаас салбарын тогтвортой сэргэлт, хамтын ажиллагаан дахь харилцааны ангал, холбоотой салбаруудын өрсөлдөх давуу тал, үнэт зүйлс ихээхэн хамаарах болж байна. [4]

Энэ ажлаар эдийн засгийн хөгжлийн харьцангуй шинэ, динамик загвар болох кластерийг Монголын хөрсөнд буулгахаар туршиж байгаа үйл явцыг харуулж, улмаар кластерийн бодлого боловсруулах нь зайлшгүй болж байгааг үзүүлэх зорилготой юм. Энэ ажлын эхний хэсэгт кластер, кластерийн санаачилгын судалгааны үр дүн, үр нөлөөг тоймлон үзүүлнэ. Дараагийн хэсэгт кластержүүлэх арга зүйг товч авч үзнэ. Төгсгөлд нь, кластержүүлэх процессийг Монгол улсад хэрэгжиж буй чацарганы кластерийн санаачилгын үйл ажиллагаагаар харуулна. Үүний үр дүнд уламжлалт салбаруудыг хөндлөн өртгийн сүлжээ рүҮ татах замаар кластерийг хөгжүүлбэл урт хугацаандаа худалдааны хамтын ажиллагааг бэхжүүлж болно. Энэ нөхцөлд кластерийн санаачилга нь богино ба дунд хугацаанд 2-3 хамгийн чухал зорилтыг хамтын ажиллагааны 
институцийг бэхжүүлэхээр сонговол эдийн засгийн бүсийг ялгаатай төрөлжүүлэх үндэс болох төдийгүй Монгол улсад кластерийн

\section{ТОЙМ СУДАЛГАА}

Глобал өрсөлдөөний орчинд, эдийн засгийн хөгжил, цэцэглэлтийг дээшлүүлэхэд бүс нутгийн хөгжлийн стратегийн үүрэг өсөж байна. Технологи болон өрсөлдөөнд өөрчлөлт хурдацтай явагдаж байгаагийн улмаас байршлын уламжлалт онолын үүрэг буурч байна. [5] Хоорондоо холбоотой компаниуд газарзүйн байршлаар төвлөрөх буюу кластерийн загварын хэрэглээ өсөж байна. Улс орны эдийн засгийн хөгжил цэцэглэлтэнд эдийн засгийн бүсүүдийн гүйцэтгэл, үр нөлөө их болж байна.

Глобал эдийн засгийн хөгжлийн динамик бүтцийн өөрчлөлтөнд нэг талаас, олон улсын эдийн засаг, аж үйлдвэрийн зохион байгуулалт, бизнесийн стратеги, инноваци; нөгөө талаас уламжлалт онол хүчтэй байгаа үед шинэ парадигмыг, тэр дундаа эдийн засгийн газарзүйн асуудлыг [6] эргэн харахад маргаантай, шийд нь шууд гарахгүй бодлого их олон. Гол нь ялгаа, ялгаварлал, ялгаатай байдал гэсэн ойлголт эдийн засгийн хувьд газар-нутаг дэвсгэрийг тодорхойлох гол шинж болсон. Гэтэл Кругман (1991), Фужита ба бусдын (1999) эдийн засгийн ухаанд, харин Скотт (1998), Стоптер болон Салаис нарын (1997) газарзүйн ухаанд гол бүтээлээ гаргаж байх үед эдийн засгийн газарзүйн хүрээ, судалгаа, шинжилгээний ажилд нийцтэй цэс тодорхой болоогүй байсан. [7]

Нөөцийг илүү үр өгөөжтэй ашиглах, глобал өрсөлдөөнд бэлэн байх талаас авч үзэхэд кластерийн, тэр тусмаа эдийн засгийн бүсээр газарзүйн байршилд төвлөрүүлэн хөндлөн өртгийн сүлжээний дагуух холбоотой салбаруудын өрсөлдөх давуу талаа бэхжүүлэх боломжийг судлах нь динамик, мэдлэгт тулгуурласан эдийн засагт нэн чухал. Майкл Портерийн сүүлийн 40 жилийн судалгаа өрсөлдөөн, өрсөлдөх бодлого боловсруулах нь зайлшгүй гэдгийг үзүүлнэ.

чадварын стратеги, өрсөлдөх давуу тал, улс үндэстний өрсөлдөх чадвар, кластер, үнэт зүйлсийг харилцан солилцох байдал гэсэн зургаан асуудалд төвлөрчээ. [8]

Газарзүйн байршлаар төвлөрсөн өртгийн сүлжээний дагуу холбоотой салбарууд хоорондоо мэдээлэл, мэдлэг, чадвар, түүхий эд/орц, эрэлт болон бусад холбоосоор холбогдож кластерийг үүсгэж байгаа юм. Эндээс хоёр төрлийн үр дагавар ажиглагдаж байна. Нэгдүгээрт, эдийн засгийн газарзүйн хил хязгаар зөвхөн нэг улсын доторхи орон нутаг, хот, том хотуудын хил хязгаарыг давж, орон нутаг, хот, том хотуудыг газарзүйн байршлаар үндэсний дэд бүс болгон авч үзэж байна. Хоёрдугаарт, анхны нөөцийнхөө ашиглалтын боломжоос хамааран газарзүйн байршил нь өрсөлдөх чадварт нөлөөтэй байгаа учраас хөрш зэргэлдээ улс хооронд инноваци, технологийн шилжилт, тэр тусмаа мэдлэгийн шилжилт хүчтэй явагдаж байна. Тиймээс эдгээр орнуудад кластерт суурилсан тоо мэдээллийн эрэлт хэрэгцээ үүсэж байгаа юм. [9] Түүнийг бүс хоорондын кластерийг харьцуулах судалгаанд ашиглах төдийгүй бодлого боловсруулагчдад бүс нутгийн стратегийг тодорхойлоход дэмжлэг болно гэж үзэж байна. [10]

Улс орны хөгжил цэцэглэлтийг илэрхийлэх кластерийн тогтсон цэс гэж байхгүй, харин кластерийн цэсэнд улс орны анхны нөөц, макро ба микро эдийн засгийн өрсөлдөх чадварыг бэхжүүлэх суурь асуудал зайлшгүй багтана. [11] Иймд юуны түрүүнд кластерийн даймонд шинжилгээ хийж, кластерийн нөхцөл байдлыг шинжилсээр ирсэн. [12] Энд хүчин зүйлсийн нөхцөл байдал; компаниудын стратеги, өрсөлдөөний бодлого; эрэлтийн 
нөхцөл байдал; бие биенийгээ дэмжих болон холбоотой салбаруудын үйл ажиллагаа гэсэн дөрвөн хүчин зүйлсийн хүрээнд зардлыг бууруулах, зардлаа харилцан хуваалцах зөвшилцөл зайлшгүй. [13] Зах зээлийн гадаад орчны ийм шинжилгээний үр дүн бол холбоотой салбаруудын өртгийн сүлжээний шат дамжлага бүхэн дэх зардлыг бууруулж, үйлчлүүлэгчийн төлөхөд бэлэн байх өртөг буюу нэмүү өртөг бүтээх үйл явцыг дэмжиж өгнө. [14], [15], [16]

2003 онд хийгдсэн Глобал кластерийн санаачилгын түүвэр судалгаанд 500 кластерийн санаачилгыг хамруулснаас гарсан гол үр дүн бол кластерийн санаачилга болгон цорын ганц буюу өөрийн онцлогтой; кластерийн санаачилгын 89 хувьд чиглүүлэгчийн үүрэг чухал байсан; кластерийн санаачилга чухал хийгээд түүний үр өгөөж, түүнийг дэмжих асуудлыг тайлбарлаж, үзэл бодлоо хуваалцах бүтцийг гаргахад нийт ажилласан цагийн 78 хувийг зарцуулсан, ийм бүтцийг гаргах талаас авч Үзвэл кластерийн өөрийнх нь давуу ба сул талыг тодорхойлж, чадавхийг үнэлэх ажил 89 хувийг эзэлсэн; кластерийн санаачилга нь алсын харааг гаргах (84 хувь), зорилттойгоо холбон үйл ажиллагаагаа төлөвлөх (68 хувь), үйл ажиллагааны төвлөрөх хэсгийг зөвшилцөх (83 хувь) рүҮ илүҮ хандаж байжээ. Кластерийн санаачилгын 95 хувь нь 10 ба түүнээс илүү идэвхтэй гишүүнтэй байсан. Кластерийн санаачилгын 40 хувийн амжилт нь нэг гол хувь хүнээс хамаарч байсан. Иймд кластерийг хөгжүүлэхдээ кластерийн санаачилгыг дэмжиж, түүнд холбогч гүүрийн үүрэг чухал байгааг түүвэр судалгаа, хэрэгжүүлсэн болон хэрэгжүүлж буй төслүүдээс харагдаж байна. [17]

Кластерийн загварыг шүүмжлэх хандлага бий. Гол асуудал бол хөгжлийн олон хэмжээст ойлголтыг нэг дор, нэгэн зэрэг загварчилах нь боломжгүй. Иймд бизнесийн динамик өөрчлөлтийг холбоотой салбаруудаар хэмжиж үзүүлэх арга зүйг сүүлийн 10 гаруй жилийн хугацаанд судлаачид хэлэлцүүлсээр хүлээн зөвшөөрөх түвшинд хүрч байна. Энэ бол кластерийн зураглалын арга. [18] Хөндлөн өртгийн сүлжээний дагуух холбоотой салбаруудын эдийн засгийн үйл ажиллагаа бөөгнөрөх нь эдийн засгийн газарзүйн төвлөрөх асуудал (Маршалл, 1920; Портер, 1990; Эллисон, Глейсэр, 1997), бөөгнөрлийн улмаас гурван ялгаатай хөдөлгөгч хүчийг (Маршалл, 1920) тодорхойлж гаргасан нь орц-гарц, хөдөлмөрийн зах зээлийн шилжих хөдөлгөөн, мэдлэгийн тархац бөгөөд эдгээрийн суурь шалтгаан салбар хоорондын зардалтай холбоотой байсан. Хэдийгээр кластерийн хэлбэржүүлэлт ялгаатай ч салбар хоорондын холбоотой байдлыг гаргах зорилгоор кластерийн тодорхойлолтын бенчмаркийг гаргахаар судлаачид ажиллаж байна. Холбоотой салбаруудыг кластераар шинжлэхдээ ажлын байрны тооны өсөлт, патент, шинэ бизнесийн хэлбэржилтээр (Портер, 2003; Фейзер болон бусад, 2008; Глейсэр болон Керр, 2009; Делгадо болон бусад, 2010, $20146)$ бүс нутгийн болон салбарын эдийн засгийн гүйцэтгэлийг статистикийн тоо мэдээлэлд тулгуурлан гаргасан.

Хөгжлийн динамик процессийг шинэ өнцгөөс харахдаа хөндлөн өртгийн сүлжээний дагуух холбоотой салбаруудын өрсөлдөх давуу талыг онцолж, инновацийн ба инновацийн бус бодлогыг хослуулан хэрэглэн дотоодын эрэлт болон экспортын орлогын урсгалыг тэлж, улмаар улс орны үндэсний нийт орлогын урсгалыг тэнцвэртэй, тогтвортой, динамик байдлаар шинжлэх нөхцөлийг эрэлхийлсээр эцсийн дүндээ бизнесийн судалгааны статистик тоо мэдээлэлд инноваци нэвтэрч эхэлсэн үр нөлөөг илэрхийлж байна. [19] 


\section{КЛАСТЕРИЙГ ХӨГЖУУЛЭХ АРГА ЗУЙ}

Кластер нь эдийн засгийн хөгжил цэцэглэлтийг харуулахдаа улс орны өрсөлдөх давуу талыг онцолно. Үүнд: кластерийн түүх, өрсөлдөөний түвшин, худалдан авагчид ба нийлүүлэгчдийн давуу тал, өрсөлдөх чадварын түвшин, технологийн түвшин гэх зэрэг бизнесийн орчны гол хүчин зүйлсийг үндэсний, бүс нутгийн, орон нутгийн хэмжээгээр шинжилнэ.

Эдийн засгийн динамик хөгжлийн процессийг авч үзэхдээ бизнесийн бөөгнөрлөөр төвлөрөх хүн амын тоонд үндэслэж болох юм. Нэг талаас, бизнес газарзүйн байршлаар бөөгнөрөхөд зах зээлийн үйл хөдлөлд үндэслэсэн эрэлт рүY чиглэсэн том хэмжээний тоо өгөгдөл Үүсэх болж байна. Нөгөө талаас, аж үйлдвэрийн салбарыг инноваци болон мэдлэг, төрөлжилтөөр байршуулж болох юм. Эндээс бид тухайн газарзүйн байршилд төвлөрсөн бизнесийн регистрийн сан болон хүн амын тоог гарган авч болно гэж үзэж байна. Энэ бол кластерийн зураглалын суурь ойлголт. Үнэндээ кластерийн зураглал бол бизнесийн стратеги, өрсөлдөх давуу тал болон нөөц, алсын хараа руугаа чиглэсэн төрийн бодлого гэх зэрэг асуудлын хоорондын уялдаа холбоог сайжруулах замаар хамтын ажиллагааны институцийн глобал орчинд дасан зохицож буй байдал, шинэ шинэ бүрэлдэн тогтож байгаa хэлбэрийг 3D аргаар үзүүлж байгаа болно.

Дэлхийн улс орнуудын зарим нь баян байхад зарим нь ядуу. Зарим улс орнуудын хөгжлийн бодлого мэдлэг бүтээх, дамжуулах руу чиглэж байхад заримынх нь өөрт байгаа анхны нөөцийн ашиглалтаа эдийн засгийн үр өгөөжтэй болгох руу илүү чиглэж байх жишээтэй. Аль ч тохиолдолд дотоодын эрэлтийг хангах хийгээд экспортын орлого татахад чиглэж, үндсэндээ эдийн засаг дахь орлогын урсгалыг л нэмэгдүүлэхэд оршино.

Кластерийг хөгжүүлэхдээ кластерийн санаачилгын хэрэгжилтийн ашиглавал анхны нөөцийн ашиглалт, түүнийг цаашид хувиргах олон янзын процесс, улмаар эдийн засаг дахь орлогын урсгалыг бизнесийн мөчлөгийн гольдрол руу илүү хандуулах болж байгаа юм. Кластерийн санаачилгын хэрэгжилтийн загвар дөрвөн бүрэлдэхүүн хэсэгтэй: үндэсний хэмжээнд нийгэм, улс төр, эдийн засгийн орчин руу чиглэнэ (1); кластерийн санаачилгын зорилго, зорилтыг тодорхойлно (2); кластерийн санаачилгын хүрээнд хийгдэх үйл ажиллагаа, түүний нөлөөг шинжилнэ (3); кластерийн санаачилгыг хэрэгжүүлнэ (4). Кластерийн санаачилга бол хөгжиж буй болон шилжилтийн эдийн засагтай орнуудад эдийн засгийн бодлогын шинэ арга хэрэгсэл болж байна. Кластерийн санаачилгын хүрээнд кластерийн компаниуд, засгийн газрын байгууллага, судалгааны байгууллага, санхүүгийн институц хамтран ажилллах юм. Үндэсний болон орон нутгийн түвшинд ялгаатай байдлаар хэрэгжүүлж болох ч зорилго зорилт, санхүүжилт, хамтрагч тус бүрийн үүрэг функц анхнаасаа тодорхой, нарийн, үйл ажиллагаа руу чиглэнэ.

Салбарын хөгжлийн үйл явцаас харахад засгийн газрын бодлого салангид, тухайлбал, салбарын бодлого, бүс нутгийн бодлого, ЖДҮ-ийн бодлого, инновацийн бодлого гээд тус тусдаа хэрэгжиж байна. Кластерийн санаачилгын хэрэгжилтийн загвар нь инноваци, өрсөлдөөн, хүрээлэн буй орчны зохицуулалт, бодлогын тогтвортой болон урьдчилан таамаглах боломж гээд өргөн хүрээгээр бодлогыг авч үзнэ. Шийдвэр гаргалт үндэсний, бүс нутгийн, орон нутгийн түвшний алинд илүҮ хамаарч байгааг харуулна. Мөн засгийн газрын кластерийн бодлого, кластерийн санаачилгыг дэмжиж буй байдлыг шинжлэх юм.

Кластерийн санаачилгын дийлэнх нь өндөр хурдны технологи, жишээлбэл, биотехнологи, харилцаа холбооны 
технологи, мэдээллийн технологи руу илүу чиглэжээ. Зарим нь уламжлалт салбар руу, тухайлбал, хүнс, нэхмэл, аялал жуулчлал, мод гэх зэрэг салбарт хэрэгжсэн. Зарим кластерийн санаачилга судалгаа болон инновацийн бодлогын санаачилгуудтай илүү ойрхон холбогдож, судалгааны лаборатори, шинжлэх ухаан технологийн паркийг хөгжүүлэх тал руу хандсан. Зарим кластерийн санаачилга тухайн улс орны хамгийн хуучин салбарыг ч дахин хөгжүүлэхээр төсөл хэрэгжүүлжээ. Статистик шинжилгээнээс харахад кластерийн санаачилгын гол зорилтыг багцлан авч үзэхэд 6 бүлэглэж болохоор байна. Судалгаа, бодлого, худалдааны хамтын ажиллагаа, боловсрол ба сургалт, инноваци ба технологи, кластерийн тэлэлт зэрэг юм.

Кластерийн ажиллагаанд санаачилгын төлөвлөлт, засаглал, санхүүжилт, гишүүнчлэлийн хүрээ, бүтцийн хүрээ, хэрэгжүүлэх хугацаа гэх зэргийг багтаж, анхнаас нь кластерийн санаачилгын менежментийн зөв бүтэцтэй байхыг зайлшгүй гэж үздэг. Хөгжиж буй орнуудын уламжлалт салбарт кластерийн санаачилгыг хэрэгжүүлж, үйл ажиллагаагий нь дэмжихдээ өртгийн сүлжээ, нийлүүлэлтийн сүлжээ рүҮ хандуулж хөгжүүлэх бодлогын хэрэгсэл дэлгэрч байна. Кластерийн санаачилгын хэрэгжилтийг гурван үзүүлэлтээр хэмжинэ. Үүнд: инноваци, олон улсын түвшинд өрсөлдөх чадвар (1); кластерийн өсөлт (2); зорилгын биелэлт (3). Эдгээрийн үндэс нь холбоотой салбаруудын өрсөлдөх давуу тал юм. Тиймээс кластерийн судалгаанд газарзүйн байршлаар салбарын өртгийн хөндлөн сүлжээ үүсгэх болон холбоотой салбаруудыг хөндлөн сүлжээнд нэгтгэхэд тулгарч буй асуудлыг алхам алхмаар шийдэх нь зайлшгүй болж байгаа юм.

\section{Чацарганы кластерийн санаачилгын төслийн эхлэл, явц}

Монголулсад 1965 оноосанхныжимсний станц байгуулагдсанаар чацаргана тариалж эхэлсэн. 29 мянган га талбайд чацаргана ургаж байсан гэсэн баримт байдаг. 1 га-д 1200-1600 бут тариалж, 1 модноос 5-30 кг, харин 1 га-гаас 5 тонн жимс хураан авах бололцоотой гэсэн судалгаа ч байдаг.

1965-1990 он хүртэлх хугацаанд жимсний салбар тасралтгүй үйл ажиллагаа явуулж байсан ч 1990-2010 хүртэл хугацаанд тогтолцооны өөрчлөлтийн улмаас зогсонги байдалд орж, 2010 оноос хойш дахин сэргэж эхэлсэн. Энэ нь 2010-2016 онд хэрэгжүүлсэн Чацаргана хөтөлбөртэй шууд холбоотой юм.

2015 оны байдлаар улсын хэмжээнд 5900 гаруй га талбайд жимс, жимсгэнэ тариалж байгаагийн 90 гаруй хувийг чацаргана эзэлжээ. 2041.2 тонн жимс жимсгэнэ хурааж авснаас чацаргана 81 хувийг эзэлсэн. Нийт 2494 мянган ширхэг суулгац үйлдвэрлэснээс чацарганы суулгац

\section{6 мянга байжээ. [17]}

Монгол улсын жимс жимсгэний салбарт чацаргана өрсөлдөх давуу талдаа тулгуурлан хөгжихийн тулд хамтын ажиллагааны институцийг бэхжүүлэхийг гол стратеги болгосон. Чацарганы кластерийн гол тоглогчид болон дэмжигчдийг үүрэг, хариуцлагын дагуу уялдуулж, өрсөлдөх давуу талаа бэхжүүлэхдээ бага зардал ба бүтээгдэхүүний ялгаварлалд илүу анхаарч, жимс жимсгэний зах зээлийн дам нөлөөг бууруулахаар ажиллахдаа хамтын ажиллагааны институцийг хөгжүүлэх болж байгаа юм. Энэ хүрээнд 2016-2018 онд чацарганы өртгийн сүлжээний гол тоглогчдыг хөндлөн сүлжээ рүү татаж, дотоодын болон экспортын эрэлтийг хангахуйцаар худалдааны хамтын ажиллагааг сайжруулах нь нэн тэргүүний зорилт юм. Чацарганы салбарын орц, эрэлт, компаниудын өрсөлдөөний бодлого, холбоотой салбаруудын (даймондын дөрвөн 
хүчин зүйл) нөхцөлд дүн шинжилгээ хийж үзэхэд хамгийн их трансакцийн зардал бол уян хатан логистик бүрэлдэж чадаагүйтэй холбоотой, мөн өртгийн хөндлөн сүлжээ рүҮ компани бүр зардлаа багасгахаар мэдлэг, мэдээлэл, нөөцөө харилцан хуваалцахгүй байгаатай холбоотой. Тиймээс чацарганы даймондын дөрвөн хүчин зүйлийг хооронд нь уялдуулахад холбогч, манлайлагчийн үүрэг зайлшгүй чухал болж байна.

\section{Зураг 1. Чацарганы салбарын даймонд}

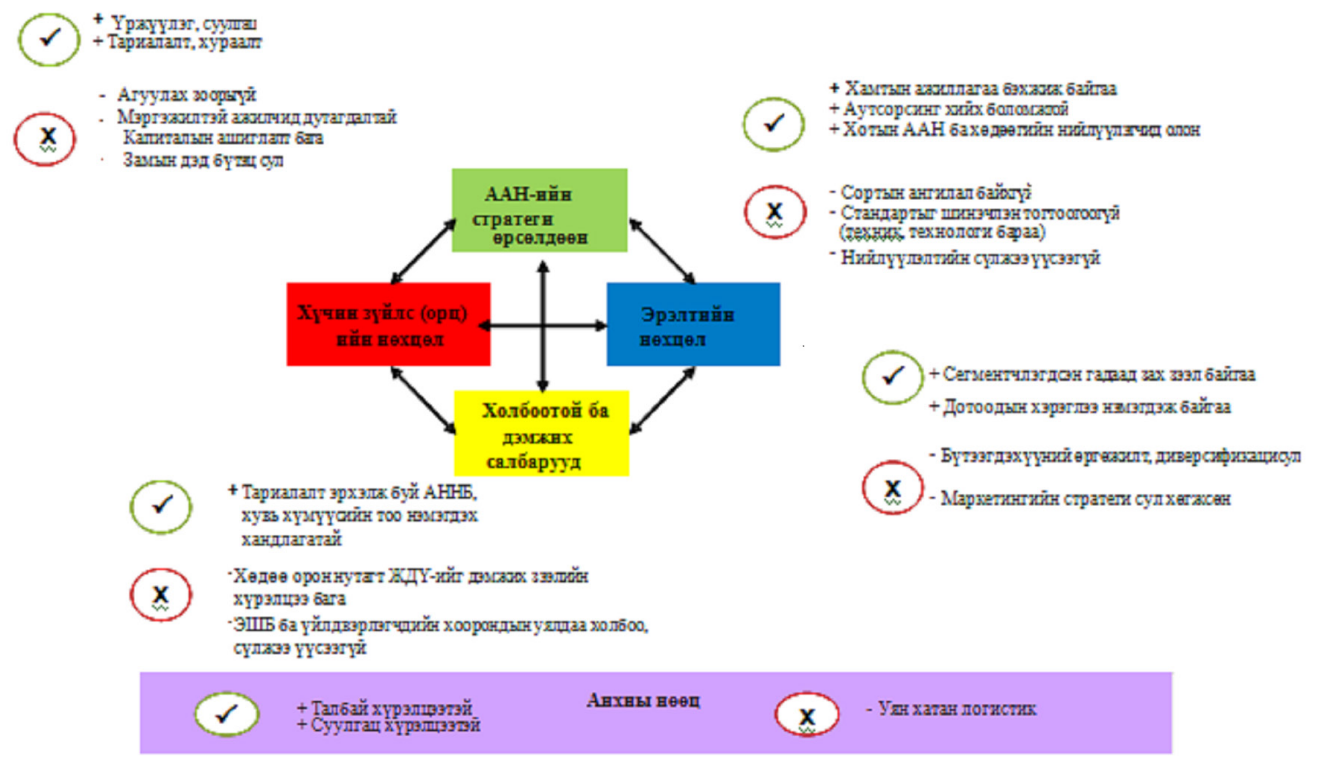

Эх сурвалж: Хорхе Валлежио [20], Х.Цэвэлмаа [21], 2012

Хүснэгт 1. Чацарганы салбарын гол хүндрэл, сорилт

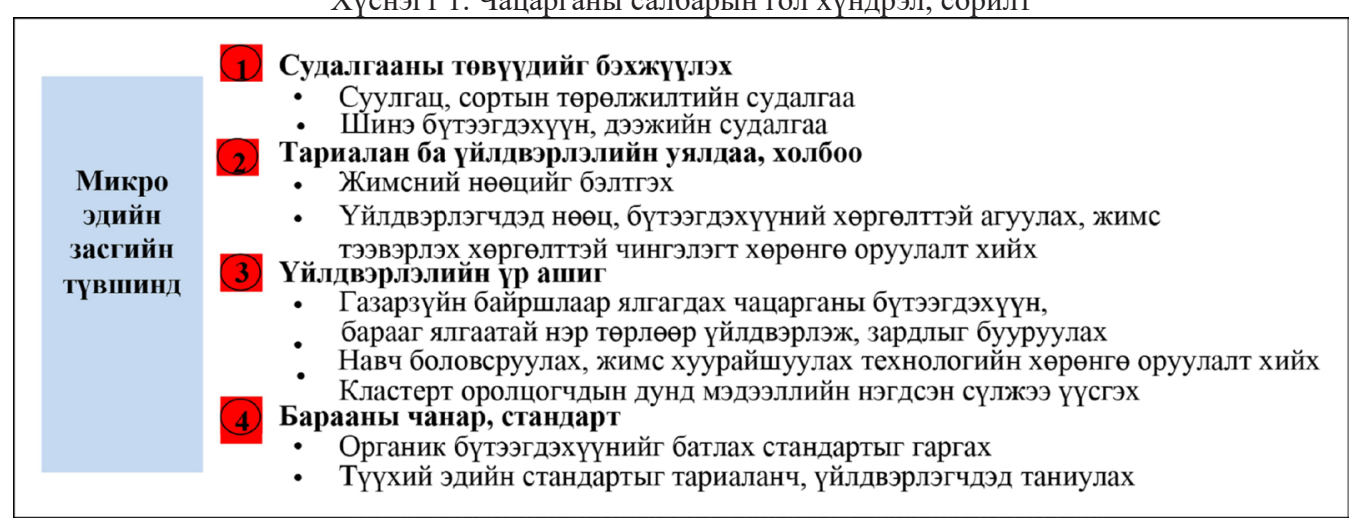

Эх сурвалж: Хорхе Валлежио [22], Х.Цэвэлмаа [23], 2012; иинэчлэгдсэн Х.Цэвэлмаа [24], 2016

“Өрхүүдийн жимс жимсгэний хэрэглээний талаарх түүвэр судалгааны үр дүн”-гээс харахад нийт өрхийн 95.6 хувь нь жимсэнд дуртай, 1.7 хувь нь дургүй, харин 2.8 хувь нь мэдэхгүй гэж хариулсан. Жимсэнд дуртай өрхүүдийн долоон хоногт зарцуулах хамгийн их хэмжээ нь 55000 төгрөг; өрхүүдийн 13.3 хувь нь долоон хоногт дунджаар 5000 төгрөг, 17.2 хувь нь долоон хоногт дунджаар 10000 төгрөг, 7.5 хувь нь 
долоон хоногт дунджаар 15000 төгрөг, 11.4 хувь нь долоон хоногт дунджаар 20000 төгрөг, 4.2 хувь нь долоон хоногт дунджаар 30000 төгрөг зарцуулдаг гэжээ. Нийт өрхийн 31.4 хувь нь 2000 оноос хойш жимс, жимсгэнийг тогтмол хэрэглэх болжээ. Нийт өрхийн 84.2 хувь нь чацаргана, түүний бүтээгдэхүүнийг хэрэглэдэг, хэрэглэхдээ байгалийн чацарганыг түлхүү буюу 56.7 хувь, таримал чацарганыг 6.4 хувь, аль аль нь хэрэглээнд ялгаагүй нь 36.9 хувь байна. Чацарганыг нийт өрхийн 76.9 хувь нь өвөл, 29.7 хувь нь хавар, 14.2 хувь нь зун, 20 хувь нь намар хэрэглэдэг. Эмчилгээний ач холбогдолтой (53.3\%) гэж үзэж байгааучраас намар болон өвлийн улиралд хэрэглэж байна. Өрхийн чацарганы хэрэглээнд шүүс (80\%), жимс (65.8\%), чанамал (28.6\%), тос $(24.4 \%)$, чацаргана орсон эмчилгээний бүтээгдэхүүн (12.2\%) давамгай хандлагатай байна. Өрхүүдийн 84.4 хувь нь чацарганыг Монголын “брэнд бүтээгдэхүүн” болж хөгжинө гэдэгт итгэлтэй байна. Өрхүүд нэрс (50.6\%), аньс (44.2\%), гүзээлзгэнэ $(22.2 \%)$, үхэр нүд $(21.9 \%)$, хад $(17.8 \%)$, тошлой $(3.3 \%)$ гэх зэрэг байгалийн жимс жимсгэнийг хэрэглэж байна. Өрхүүдийн жимс жимсгэний худалдан авалтанд: эрүүл мэнд (48.6\%), амт (29.4\%), үнэ (48.1\%), олдоц (16.7\%), өрхийн орлого (13.9\%) гэх зэрэг хүчин зүйлс нөлөөлжээ. [25]

"Монгол улсын жимс жимсгэний тариалагчдын судалгааны үр дүн”-гээс харахад: нийт 308 тариаланч компани, өрх судалгаанд оролцсоноос том тариалагч 36 байсан байна. Тариалангийн дундаж талбай 13 га байжээ. Хамгийн том 6 аж ахуйн нэгжийг оруулалгүй тооцвол нэг байгууллагад ноогдох тариалсан талбайн хэмжээ 9,93 га байсан. Хураасан ургацынхаа 22.7 хувийг өрхийн үйлдвэрлэлд, 8.8 хувийг бөөнөөр нь боловсруулах үйлдвэрт, 13 хувийг худалдааны сүлжээнд, 19.8 хувийг өөрсдийн хэрэгцээнд, 8.8 хувийг хадгалах, нөөцлөх гэх зэрэг бусад зах зээлд нийлүүлж байжээ. Чацарганы тариаланд тулгарч буй асуудлыг нөөц хүрэлцээгүй
(16.2\%), тариалалт, үйлдвэрлэл уялдаагүй (39.9\%), хувийн хэвшлийнхний санаачилга дутмаг (17.9\%), хөнгөлөлт, урамшууллын хөшүүрэг дутмаг $(33.8 \%)$, салбарын цогц судалгаа хийгдээгүй $(17.2 \%)$, сортын суулгацын нийлүүлэлт дутмаг $(17.2 \%)$, тээврийн сүлжээ Үүсээгүй $(26.6 \%)$, агуулахын сүлжэээ үүсээгүй (29.5\%), борлуулах бүтээгэхүүний хэмжээ бага (30.2\%) гэж тодорхойлжээ. Жимс жимсгэний тариалагчид бүтээгдэхүнээ худалдааны сүлжээ (57.5\%), боловсруулах үйлдвэрт $(42.5 \%), \quad$ сургууль цэцэрлэг (36.7\%), эмнэлэг сувилал (31.2\%), экспорт $(25 \%)$, уул уурхайн компани $(19.5 \%)$, хүчний байгууллага (4.9\%)-д нийлүүлэх сонирхолтой байжээ. Хураасан жимс жимсгэнийг хүнсний $(68.2 \%)$, эрүүл мэнд, эмчилгээний $(43.2 \%), \quad$ байгаль хамгааллын (21.1\%), үржүүлгийн (14.6\%) бүтээгдэхүүнд илүү нийцнэ гэсэн. Тиймээс цаашид байгаль хамгаалах (54.2\%), хүн амын эрүүл мэндийг хамгаалах (48.7\%), аж ахуй өрхийн орлогыг нэмэгдүүлэх (48.1\%), хүнсний хангамжийг сайжруулах (41.9\%), ажил эрхлэлтийг дэмжих (38.0\%) чиглэл рүY хандуулах саналтай байгаагаа илэрхийлсэн. Нийт тариалагчдын 44.8 хувь нь жимс жимсгэний зах зээлийг улсын хэмжээнд, 21.4 хувь нь бүсийн хэмжээнд, 10.1 хувь нь аймаг хооронд, 13 хувь нь аймаг, дүүрэг дотор нийлүүлэлт, борлуулалтын сүлжээ үүсгэн хөгжүүлэхийг санал болгож байсан. [26]

2014 онд хийгдсэн судалгаагаар чацарганы өртгийн сүлжээний анхан шатны болон дэмжих үйл ажиллагааны хүндрэлийг илрүүлсэн байна.[27]

2015 онд Чацарганы кластерийн санаачилгын менежментийг тодорхойлж, үйл ажиллагаанд тасалдал үүссэн. Гэсэн хэдий ч салбарын үйл ажиллагааг тасралтгүй уялдуулах гүүрийн үүргийг “Чацарганы кластерийн санаачилга"-ын баг гүйцэтгэж байна. [28]

2016 онд хийгдсэн "Компаниудын судалгаa”-ны үр дүнгээс харахад: 
Улаанбаатар хотод жимс жимсгэнийг боловсруулах чиглэлээр 20 орчим компани үйлдвэрлэл эрхэлж байгаагаас энэ удаагийн судалгаанд 14 компани оролцсон. Харин Увс аймагт голдуу тариалалт эрхэлж буй 10 компани, тариалалт-үйлдвэрлэлийг хосолсон 5 жижиг ба 1 том үйлдвэрлэгч компани (Увс хүнс ХК), нийтдээ 16 компани судалгаанд оролцлоо. Компаниуд жимс жимсгэнэ боловсруулах чиглэлээр дунджаар 8 жил дагнан ажилласан туршлагатай байна. Боловсруулах компаниудын үйлдвэрийн хүчин чадал харилцан адилгүй. Судалгаанд оролцсон компаниудын 65.4 хувь нь 50 хүртэл тонн жимс жимсгэнийг жилд боловсруулах хүчин чадалтай, ихэнхдээ жижиг үйлдвэрлэгчид байна. Компаниудын 17.1 хувь нь 50-100 тонн жимсийг; 17.5 хувь нь 100 ба түүнээс дээш тонн жимсийг жилд боловсруулах хүчин чадалтай байна. Хүчин чадлаа бүрэн дайчлан ажиллах боломжтой ч жимсний нөөц бэлтгэлийн асуудлыг алхам алхмаар шийдэхээр ажиллаж байна. [29]

Хүснэгт 2. Чаиарганы өртгийн сүлжээ

\begin{tabular}{|c|c|c|c|c|c|}
\hline \multirow{4}{*}{ 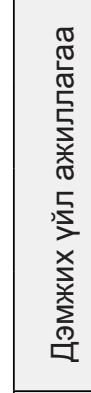 } & \multicolumn{5}{|c|}{$\begin{array}{l}\text { Компанийн дэд бүтэц: санхүү, төлөвлөлт, хөрөнгө оруулалтын дэмжлэг яамд } \\
\text { хооронд уялдаагүй }\end{array}$} \\
\hline & \multicolumn{5}{|c|}{$\begin{array}{l}\text { Хүний нөөцийн менежмент: шинэ ажиллах хүч, сургалт, нөхөн олговрын тогтолцоог } \\
\text { салбарын түвшинд шинжлээгүй }\end{array}$} \\
\hline & \multicolumn{5}{|c|}{$\begin{array}{l}\text { Технологийн хөгжил: бүтээгдэхүүний загвар, чанарын шалгалт, түүхий эд ба зах } \\
\text { зээлийн судалгааны дэмжлэг сул }\end{array}$} \\
\hline & \multicolumn{5}{|c|}{$\begin{array}{l}\text { Засгийн газрын худалдан авалт: хураалтын машин тоног төхөөрөмж, үйлчилгээний } \\
\text { хувьд дэмжлэг байгаа ч жимсний нөөц, жимсний бүтээгдэхүүний худалдан авалтын } \\
\text { дэмжлэг илүү тулгамдаж буй асуудал }\end{array}$} \\
\hline \multicolumn{2}{|c|}{$\begin{array}{l}\text { Үйлдвэрлэлийн } \\
\text { өмнөх логистик }\end{array}$} & Үйлдвэрлэл & олэлийн & $\begin{array}{l}\text { Жижиглэн/ } \\
\text { Маркетинг }\end{array}$ & $\mid \begin{array}{c}\text { Жижиглэнгийн } \\
\text { дараах үйлчилгээ } \mid\end{array}$ \\
\hline \multicolumn{2}{|c|}{$\begin{array}{c}\text { Үр суулгац, } \\
\text { бордоо, ургамал } \\
\text { хамгаалал, } \\
\text { усалгаа, хураалт }\end{array}$} & $\begin{array}{c}\text { Жимсний хагас } \\
\text { боловсруулсан } \\
\text { болон эцсийн } \\
\text { бүтээгдэхүүн }\end{array}$ & $\begin{array}{c}\text { Хадгалалт, } \\
\text { тээвэрлэлт, } \\
\text { захиалга }\end{array}$ & $\begin{array}{c}\text { Хүнсний сүлжээ } \\
\text { дэлгүүр, их } \\
\text { дэлгүүр, эмийн } \\
\text { сан гэх мэт }\end{array}$ & $\begin{array}{c}\text { Хэрэглэгчдийн } \\
\text { сонирхлын } \\
\text { өөрчлөлт }\end{array}$ \\
\hline \multicolumn{6}{|c|}{ Анхан шатны үйл ажиллагаа } \\
\hline
\end{tabular}

Эх сурвалж: Чаџарганы кластерийн санаачилга, 2016

Үйлдвэрлэлийн өмнөх логистикийн үе шатанд хангалттай тооны компаниуд ажиллаж байгаa ч тариалалт, хураалт, хадгалалт, зөөвөрлөлт, тээвэрлэлтийн асуудлыг эргэн харж, цогц байдлаар шийдэх гарцыг хайж байна.

Чацарганы боловсруулах үйлдвэрүүд үйлдвэрлэлийн дараах логистикийн асуудлыг хамтатган шийдэж байгаагийн улмаас трансакцийн зардал өндөртэй. Энэ салбарт үйлдвэрлэлийн дараaх логистикийг дагнан гүйцэтгэх компаниуд төрөлжиж хөгжөөгүй, цаашид салбарын үйл ажиллагаа тогтворжин шинэ зах зээл рүу нэвтрэх тохиолдолд логистикийн тогтолцоог сууриар нь шинжлэх шаардлага Үүсэж болох юм.

Анхан шатны үйл ажиллагааны жижиглэн/маркетингийн шатны гол бэрхшээл бол төлбөр тооцооны хоцрогдол. Үүнээс болж салбарын үйл ажиллагаанд саатал үүсэх магадлал их өндөр. Тиймээс 
өртгийн сүлжээний санхүүжилтийн шинэ шинэ бүтээгдэхүүн, үйлчилгээний эрэлт ихсэж, өртгийн сүлжээнд санхүүгийн институцийн дэмжлэг зайлшгүй болж ирсэн. Үүний зэрэгцээ анхан шатны үйл

\section{ДУГНЭЛТ, САНАЛ}

ЧКС-ын хэрэгжүүлэх явцаас гарч буй үр дүн бол уламжлалт салбарыг, тухайлбал, чацарганы салбарыг өртгийн хөндлөн сүлжээний дагуу хөгжүүлж, Монгол улсад жимс жимсгэний кластер үүсэх боломжтой. Уламжлалт, инновацийн бус салбаруудыг холбон кластержүүлэхэд урт хугацаа шаардагдах бөгөөд зардал ихтэй, бас эрсдэлтэй юм.

Монгол улсын урт хугацааны хөгжлийн үзэл баримтлалыг [30] баталсан ч салбаруудыг уялдуулан кластераар хөгжүүлэх ойлголцлын санамж бичиг, кластерийн бодлого өнөөг хүртэл тодорхойлогдоогүй байна. Иймд нэгдүгээрт, үндэсний эдийн засгийн стратеги буюу бүс нутгийн хөгжлийн стратеги; хоёрдугаарт, Монгол улсын уламжлалт салбар гол төлөв ХАА-АY-ийн хосолсон хэлбэртэй байгаа болохоор зангидах, уялдуулах яамд хоорондын ойлголцол; гуравдугаарт, засгийн газрын хөгжлийн бодлого ба хувийн хэвшлийн бизнесийн стратеги нэг чиглэлтэй байх нь кластерийг хөгжүүлэхэд зайлшгүй юм. Нөхцөл байдлыг нухацтай авч үзвэл, салбар хоорондын хөгжлийн төлөвлөлт дутагдаж, засгийн газрын дэмжлэг, зохицуулалт нь (босоо юм уу хөндлөн) өртгийн сүлжээ рүҮ хараахан чиглээгүй; хөгжлийн санхүүжилтийн асуудал нэн тулгамдсан асуудал болж байхад богино ба дунд хугацаанд яамд чиг үүргийнхээ дагуу зардлаа бууруулах, дам нөлөөг багасах тал руугаa уялдуулахгүй байна. Улс төрийн шийдвэр гаргалтын улмаас яамд хоорондын зөвшилцөл дутагдаж байна.

2016 оноос ХХААЯ-ны бүтэц ХХААХYЯ болж дахин зохион ажиллагааны эхний гурван шатанд үйл ажиллагаа явуулж буй компаниуд зорилтот зах зээл рүү хамтран нэвтэрвэл дотоодын болон гадаадын хэрэглэгчдийн эрэлт хэрэгцээг бодитой хангаж, тогтворжих юм.

байгуулалтанд орсноор ХАA-AYийн хосолсон хэлбэрийг уялдуулах нөхцөл эргээд бүрдэж байна. Чацарганы кластерийн санаачилга эхэлснээс хойш чацарганы өртгийн сүлжээний анхан шатны үйл ажиллагааны хувьд зөвхөн газар тариалангийн талд буюу үйлдвэрлэлийн өмнөх логистикт сүүлийн 2-3 жилд түлхүҮ анхаарчээ. Тиймээс чацарганы кластерийн санаачилгын менежментийн бүтцийн хүрээнд засгийн газрын болон олон улсын байгууллагын техникийн туслалцааны дэмжлэг 3-5 жилийн хугацаанд зайлшгүй байна.

Бүсчилсэн хөгжлийн үзэл баримтлалын хувьд газарзүйн байршлын нөлөө бус, харин улс төр, засаг захиргааны бүтэцтэй адилханаар эдийн засгийн бүсээ авч үзэж байгаа учраас нөөцийн ашиглалт, орцын шилжилт хөдөлгөөн, эдийн засаг дахь орлогын урсгалыг үндэсний тооцооны системийн хүрээнд бүртгэж, хэмжигдэхгүй байна. Эдийн засгийн бүсийн стратеги анхны нөөц, нөөц ашиглалт, хөдөлмөрийн оролцоо гэсэн суурь ойлголтонд үндэслэж, хөдөлмөрийн бүтээмжийн өөрчлөлтийг нэн тэргүүнд авч үзвэл аймаг нийслэл, сум дүүргүүд өрсөлдөх давуу талаа нарийвчлан шинжлэх нөхцөл бүрэлдэх юм.

Бүх аймаг ижил төрлийн бүтээгдэхүүн үйлдвэрлээд байвал өрсөлдөөн үгүй болж, зардлыг бууруулан бүтээгдэхүүний ялгаварлалыг хөгжүүлж чадахгүй, мөн өрсөлдөх давуу талаа бэхжүүлэх суурь нөхцөл хангагдахгүй л байх болно. Үүний нэг жишээ бол чацарганыг орон даяар тариална гэж эхэлж байсан бол өнөөгийн нөхцөлд жимс жимсгэний тариалан гэхэд хоёр мужид л төвлөрөх хандлагатай 
болж байна. Энэхүү газарзүйн байршилд төвлөрсөн мужид чацарганы өртгийн сүлжээний дэмжих үйл ажиллагааны хүрээнд ялгаатай цаг хугацаанд ялгаатай бодлогоор дэмжих; мөн анхан шатны үйл ажиллагааны хүрээнд шат дамжлага бүхэнд хангалттай тооны компаниудыг татан оруулж, өртгийн сүлжээний санхүүжилтийн бүтээгдэхүүн ба үйлчилгээгээр дэмжвэл дотоодын эрэлтийг хангах болон экспортын орлого татах боломжтой юм.

Өрсөлдөх давуу талдаa суурилан хувийн компаниуд өрсөлдөөний стратеги болон бодлогоо тодорхойлж, шинэ зах зээл рүY бизнесийн нэгдэл байгуулах замаар хамтран орж, газарзүйн байршлыг онилох, хэрэглэгчдийн тодорхой зах зээл рүү нэвтрэх нь уламжлалт салбарыг кластержүүлэх үндэслэл болно. Энэ нөхцөлд зөвхөн газар тариалан-хүнсний боловсруулах үйлдвэр бус, мөн аялал жуулчлал, эрүүл мэнд гэх мэт үйлчилгээний салбаруудыг хамтатган бодлогыг цогц байдлаар зангидах нь зайлшгүй. Салбар үнэт зүйлсийг бүтээхдээ алсын хараатай стратеги, түүнийг дагасан олон зорилтыг хэрэгжүүлж болох ч богино ба дунд хугацаанд гол төлөв хамтын ажиллагааны институцийг бэхжүүлэх, улмаар худалдааны хамтын ажиллагааг шинэ шатанд гарган хөгжүүлэх хэрэгтэй болж байна. Учир нь компани бүхэн зардлаа бууруулах сонирхолтой - үүний тулд өртгийн хөндлөн сүлжээнд нэгдэж болно; эдийн засгийн агент бүхэн орлого олох хүсэлтэй - хамтын ажиллагааны институцийн шинэ хэлбэрийг зах зээлийн зарчмаар төлөвшүүлэх нь агент бүрээс хамаарна; эцэстээ бүх агент эдийн засгийн орлогын урсгалыг нэмэгдүүлэхэд хувь нэмэр оруулах үүрэгтэй - хөдөлмөрийн бүтээмж дээшлэхийн хэрээр үндэсний орлого нэмэгдэж, хүн амын амьжиргааны түвшин дээшлэх болно.

Хувийн компаниуд үнэт зүйлсээ зөвшилцөн салбарын зардлыг бууруулахаар хамтрах нь глобал өрсөлдөөнд бэлэн байхад шууд нөлөө үзүүлнэ. Бүгд бүтээгдэхүүний ялгаварлалын төлөө өрсөлдвөл жимс жимсгэний кластерт инновацийг нэвтрүүлэх, олон улсын өрсөлдөөнд байгалийн болон таримал жимс жимсгэний патентаар өрсөлдөх, улмаар эдийн засгийн бусад салбартай зэрэгцэн хөгжвөл үнэт зүйлсээ хуваалцах юм. Иймээс Чацарганы кластерийн санаачилга бол Монгол улсад кластерийг хөгжүүлэх эхлэл тавигдсаныг харуулж байгаа бөгөөд цаашид өөр бусад хөндлөн өртгийн сүлжээний дагуух холбоотой салбаруудыг дэмжин хөгжүүлнэ гэвэл энэхүу санаачилгын ололт амжилт, алдаа дутагдал, аюул эрсдэл гэх зэрэгт суурилан Монгол улсын хэмжээнд эдийн засгийн бүсийн хөгжлийн стратеги, кластерийн бодлого боловсруулах шаардлагатай байна.

\section{HOM 3YЙ}

[1] HBS, ISC, MOC Impact, MOC Faculty Workshop 2016

[2] Michael E. Porter On Competition: Updated and Expanded Edition, Part II, 2008

[3] Porter, Michael E.; The Competitive Advantage of Nations. New York: Free Press, 1990

[4] O.Solvell, G.Lindqvist, C.Ketels The Cluster Initiative Green Book, 2003

[5] Porter, Michael E.; location, competition, and economic development: local clusters in a global economy, Economic Development Quarterly, Feb2000, Vol. 14 Issue 1, p15, 20p

[6] Gordon L.Clark, Maryann P.Feldman, and Meric S.Gertle, Economic Geography: Transition and Growth, Chapter 1, 2009

[7] M.Delgado, M.E.Porter, S.Stern, Clusters and Entrepreneurships, Journal of Economic Geography (2010) pp.1-24

[8] Orjan Solvell, On Strategy and Competitiveness: 10 Recipes for Analytical Success, p.16

[9] Porter, Michael E.; The economic performance of regions Regional Studies 37: 549-578 
[10] M.Delgado, M.E.Porter, S.Stern, Defining clusters related industries, Journal of Economic Geography (2015) pp.1-38

[11] Orjan Solvell, Goran Lindqvist, Christian Ketels The Cluster Initiative Green Book, 2003

[12] Christian Ketels, Goran Lindqvist, Orjan Solvell Cluster Initiatives in Developing and Transition Economies

[13] Orjan Solvell Clusters: Balancing Evolutionary and Constructive Forces

[14] Orjan Solvell and Mats Williams Building the Cluster Commons: An Evaluation of 12 Cluster Organizations in Sweden 2005-2012

[15] Orjan Solvell, On Strategy and Competitiveness: 10 Recipes for Analytical Success

[16] Orjan Solvell, Goran Lindqvist, Christian Ketels The Cluster Initiative Green Book, 2003

[17] Mercedes Delgado, Michael E. Porter and Scott Stern, Defining clusters of related industries, Journal of Economic Geography (2015) pp.1-38

[18] IKED, The Cluster Policies, White book 2004. p.158

[19] XXААХYЯ, Чацаргана хөтөлбөрийн тайлан, 2016

[20] Jorge Ramirez Vallejo, Mongolia: Building a National Value Proposition for Competitiveness Scoping Report

[21] Х.Цэвэлмаа, С.Амартүвшин Монгол улсад мах, ноос, ноолуур, арьс шир, оёдол, чацарганы кластерийг хөгжүүлэх нөхцөл байдлын үнэлгээҮХШХ, 2012

[22] Jorge Ramirez Vallejo, Mongolia: Building a National Value Proposition for Competitiveness Scoping Report

[23] Х.Цэвэлмаа, С.Амартүвшин Монгол улсад мах, ноос, ноолуур, арьс шир, оёдол, чацарганы кластерийг хөгжүүлэх нөхцөл байдлын үнэлгээҮХШХ, 2012

[24] Х.Цэвэлмаа, Чацарганы кластерийн санаачилга, 2016

[25] ХХААЯ, МЧТҮҮХ “Монгол орны таримал чацаргана, бусад жимс жимсгэний зах зээл, кластерийн судалгаa”, 2013

[26] ХХААЯ, МЧТҮҮХ “Монгол орны таримал чацаргана, бусад жимс жимсгэний зах зээл, кластерийн судалгаa”, 2013

[27] ХХААЯ, МЧТYҮХ, “Чацарганы кластерийн санаачилга”, 2014

[28] Х.Цэвэлмаа Кластер, кластерийн санаачилгыг хөгжүүлсэн орнуудын туршлагаас, 2015

[29] ХХААЯ, МЧТYYХ, Монгол чацарганыг газар зүйн заалттай бүтээгдэхүүнээр бүртгэлжүүлэх, нэгдсэн өртгийн сүлжээ үүсгэх ажлын хүрээнд хамтын ажиллагааны тогтолцоо бүрдүүлэх ажил, 2015

[30] Монгол Улсын Их Хурал, Төрийн байгуулалтын байнгын хороо, Монгол улсын тогтвортой хөгжлийн үзэл баримтлал-2030: үндэслэл, хамрах хүрээ, хуудас 62, 2016 


\title{
CLUSTERING AND SEA BUCKTHORN CLUSTER INITIATIVE
}

\author{
Kh.Tsevelmaa \\ National University of Mongolia \\ E-mail: tsvlmkhrgs@gmail.com
}

Research demand for development of clusters of related industries has risen. On the one hand, we need to understand the new thinking of dynamic economic development; on the other hand, it is a time consuming activity to collect data of related industries and analyze dynamic economic development structure. This paper aimed to show that creating a distinctive and more competitive position for a traditional related industries based on implementing best practices in each economic policy area. First part of a paper gives a brief results and impacts on cluster and cluster initiatives. Then it introduces clustering methods. Finally, paper considers clustering process in Mongolia based on Sea buckthorn cluster initiative. As a result it was visible that traditional related industries can be developed based on cluster concepts; in that circumstances, cluster initiative should choose two to three distinctive goals for developing institutions for collaborations in short and medium term; hence, it will establish a base of long term economic region's policy diversifications as well as cluster policy pilot in Mongolia.

Keywords: Cluster initiative, related industries in the horizontal value chain, cluster policy; 